\title{
Mellem Slesvig og Slovenien
}

\section{Subjektiv identitetsdannelse $i$ et sammenlignende perspektiv}

\author{
af Peter Thaler
}

Den sønderjyske historie er et emne, som traditionelt har mødt stor interesse i offentligheden. Dette skyldes ikke mindst de nationale spændinger og grænsespørgsmålet, som optog sindene til langt op i efterkrigstiden. Den folkelige forankring har været den sønderjyske historieskrivnings store styrke. Med de seneste årtiers afspænding af de nationale modsætninger har den sønderjyske historieforskning mistet noget af fordums betydning. Lektor Peter Thaler giver i denne artikel svar på, hvad der er den sønderjyske historieskrivnings styrke $\mathrm{i}$ dag og $\mathrm{i}$ fremtiden. Vejen frem er at se den slesvigske erfaring $i$ et større europæisk og teoretisk perspektiv.

Ved slutningen af Anden Verdenskrig omfattede Sydslesvigs centrale mindretalsforening ikke mere end 3000 medlemmer. I 1946 var dette tal vokset til over 10.000 , og et par år senere var det mangedoblet til omtrent 70.000. Efter 1950 faldt medlemskabet mærkbart igen, indtil det stabiliseredes i underkanten af 20.000 nogle årtier senere. Denne usædvanligt store svingning er bemærkelsesværdig. Den viser, at den nationale identitetsdannelse i Slesvig langt fra var stabil. Folk bestemte selv, hvilken nationalitet de ville tilhøre.

Den subjektive identitetsdannelse, også kaldet sindelagsprincippet, udgør kernen af dette bidrag. Men før vi tager fat på situationen i Sydslesvig efter 1945, må vi vende blikket mod den historie, der gik forud.

Da de nationale tænkemåder nåede Sønderjylland i første halvdel af 1800-tallet, var hertugdømmets sydlige halvdel allerede helt overvejende tysktalende. Med hensyn til kirke- og skolesproget gjaldt dette i hele Sydslesvig. Som hverdagssprog var frisisk fortsat fremherskende langs vestkysten. Sønderjysk var ved at blive erstattet af plattysk i Angel, men blev fastholdt i midtlandet næsten ned til Dannevirke i en spids kile, som kun langsomt veg tilbage nordover.

Efter at den slesvig-holstenske opstand var blevet slået ned i 1850, forsøgte den danske regering aktivt at styrke og sprede dansk sprog og sindelag i det midterste Slesvig. Dansk fik officiel status i områder, 
hvor det nogle år tidligere endnu havde været fremherskende som hverdagssprog. På grund af udbredt modstand i befolkningen og den korte tidsramme havde denne politik kun begrænset succes, og efter hertugdømmernes afståelse i 1864 blev den straks ophævet.

I de første valg efter indlemmelsen i Preussen var de danske stemmer fremherskende $\mathbf{i}$ det nordlige Slesvig ned til Flensborg. Også i selve byen og dens omegn lå danskerne foran, om end kun knebent. I en smal stribe vest og øst for byen udgjorde de fortsat en betragtelig faktor. Et par årtier senere var denne indflydelse gået stærkt tilbage. Uden for Flensborg var den blevet ret ubetydelig, men også inde i byen udgjorde den nu entydigt et mindretal. I de sidste førkrigsvalg var den danske stemmeandel $\mathrm{i}$ Flensborg og andre forhenværende højborge faldet til betydeligt under 10 procent. ${ }^{1}$ Kun en lille del af disse stemmer kom fra de stadigt dansktalende egne i midtlandet. Området var tyndt befolket, og de fleste sønderjysktalende, der boede her, betragtede sig som tyskere. I Flensborg havde derimod tysk fremhersket helt siden senmiddelalderen, og det var i første række tilflytningen fra oplandet, som holdt det danske sprog i live. Følgelig betegnede de fleste dansktalende i Sydslesvig sig som tyskere, mens en betragtelig del af de dansksindede brugte tysk i hverdagen. ${ }^{2}$

Under det danske styre frem til 1864 udviste Flensborgs førende familier ofte en kongetro helstatsorientering, som også skyldtes økonomiske forbindelser nordpå. Disse historiske bindinger vedblev at gøre sig gældende i den tidlige prøjsertid, men blev i stigende grad ændret af de nye politiske og særligt de nye økonomiske realiteter. Det tysktalende storborgerskab forsonede sig med det tyske rige. Flensborg udviklede sig til et centrum for danske kulturaktiviteter, ikke mindst som redaktionssæde for Flensborg Avis, der blev mindretallets vigtigste publicistiske talerør. Bærerne af denne aktivisme måtte imidlertid oftest rekrutteres $i$ andre dele af Sønderjylland.

Da Tysklands nederlag i Første Verdenskrig igen satte Slesvigspørgsmålet på den internationale dagsorden, omfattede afstemningszone $2 \mathrm{i}$ det store og hele de kommuner i det midterste Slesvig, som lå syd for H.V. Clausens sindelagsgrænse mellem dansk og tysk, men som havde opvist danske sympatier i tidligere årtier. ${ }^{3}$ Folkeafstemningen bragte højere danske stemmeprocenter end de forudgående parlamentsvalg. Alligevel var der tysk flertal i alle sogne. Det var lavere i Flensborg og omegn og højere fjernt fra byen, med undtagelse af enkelte frisiske ø-kommuner. ${ }^{4}$ 
OVERSIGT

over

Tyske Privatskoler i Nordslesvig. Danske Privatskoler i Sydslesvig og Sprogforholdene 1864

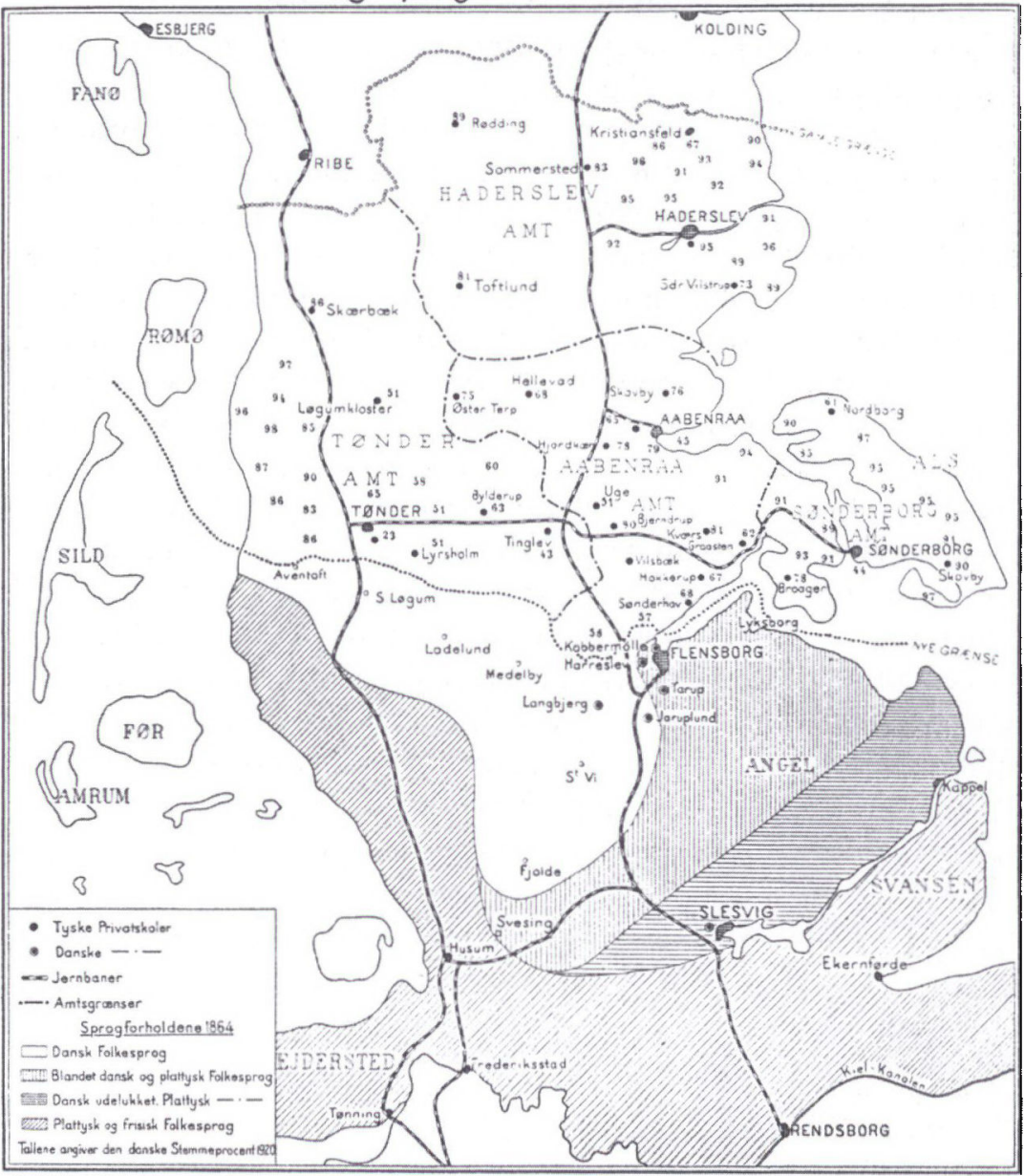

Dette kort fra begyndelsen af 1930'erne viser bade en oversigt over mindretalsskoler $i$ mellemkrigstiden og den forudgående sprogudvikling. Efter maj 1945 blev skoleforholdene vedt om. I sommeren 1947 var der lidt over 50 danske skoler $i$ gang $i$ Sydslesvig. 
Afstemningsresultatet skuffede de danske aktivister syd for den nye grænse. De fleste havde ønsket tilslutning til Danmark. I stedet måtte de nu definere sig som et nationalt mindretal. Flensborg forblev midtpunktet for danske aktiviteter. Uden for denne kernekommune beboede mindretallet $\mathrm{i}$ begyndelsen kun en smal grænsestribe og gradvis fremvoksende sydlige forposter $\mathrm{i}$ byerne Slesvig og Tønning. Overalt befandt de danske grupper sig imidlertid klart i mindretal.

Et af de mest interessante aspekter af den moderne danske befolkningsgruppe i Sydslesvig viser sig allerede i mellemkrigstiden. Mindretallets talmæssige styrke skiftede, oftest i takt med den bredere samfundsmæssige udvikling i Tyskland. I kriseperioder steg interessen for danske institutioner. Når krisen var overstået, gik også det danske foreningsliv tilbage. Selvom denne bølgebevægelse er mest synlig i efterkrigstiden, kan den allerede spores i mellemkrigsårene. I skyggen af Tysklands militære nederlag og dets medfølgende belastninger stemte 20 procent af vælgerne for Danmark i 1920. Dette tal lå betydeligt over valgresultaterne, som danske kandidater havde opnået $\mathrm{i}$ årene før. ${ }^{5}$ Den efterfølgende nedgang vendte igen under inflationen. Mens Weimarrepublikken oplevede sin korte konsolideringsfase, gik det danske mindretal tilbage, indtil den verdensomspændende økonomiske krise gav ny vind i sejlerne. Hvis man viderefører dette mønster, forekommer den økonomiske konsolidering i midten af 1930 'erne som en væsentlig faktor i mindretallets fornyede nedgang, selvom rammebetingelserne inden for et diktatur fremskyndte processen.

Denne ustabilitet optrådte i forskellige former. I Flensborg land-

Tabel 1

Medlemstal i Den slesvigske Forening i Flensborg

\begin{tabular}{ll}
\hline Nov./dec. 1920 & 4699 \\
Juni/sept. 1924 & 5797 \\
Aug./sept. 1929 & 3374 \\
Jan./juni 1933 & 3493 \\
Jan./juni 1936 & 3016 \\
Juni/sept. 1939 & 2419 \\
1944/1945 & 1882 \\
\hline
\end{tabular}

Kilde: Johan Peter Noack, Det danske mindretal $i$ Sydslesvig 1920-1947 (Aabenraa, 1989), 2:307. 
kreds opnåede danske kandidater 279 stemmer i rigsdagsvalget $\mathrm{i}$ 1921, 412 i maj-valget 1924, 151 i 1928, og 232 i november 1932. Efter samtidige opgørelser fulgte medlemstallene i Den slesvigske Forening i mellemkrigstidens Flensborg et lignende mønster (se tabel 1). ${ }^{6}$

Denne tilslutning afspejler en gruppeidentitet, som ikke hovedsageligt er grundet $\mathrm{i}$ sprog og kultur. Mindretallets organisation var bevidst om dette forhold og opfattede det derfor ikke som problematisk, at en del af mindretallets aktiviteter foregik på tysk, for eksempel gennem tysksprogede aviser. Man var opmærksom på, at der ikke måtte være store barrierer for tysksindede, som ønskede at deltage $\mathrm{i}$ mindretalsarbejdet. Omvendt accepterede man uden videre, når medlemmer meldte sig ud. Mindretal og flertal byttede bestandigt medlemmer.

Den nationalsocialistiske magtovertagelse stillede de danske institutioner over for nye udfordringer. Perifere medlemmer skiftede over på den tyske side, som også profiterede af det økonomiske opsving. Samtidig fandt hidtil tysksindede vej ind i mindretallet, hvor man kunne unddrage sig selv og sine børn ensretningen. Rigsregeringen forandrede ikke fuldstændigt kurs over for mindretallet; udenrigspolitiske overvejelser og hensyntagen til de tyske nordslesvigere talte imod dette. Lokale myndigheder forsøgte imidlertid gentagne gange at begrænse danske aktiviteter.

I første række var de danske sydslesvigere udsat for indirekte pres. Fortsat samarbejde med andre mindretal medførte fare om at blive trukket ind i den langt mere bitre tysk-polske konflikt. Endnu større var udfordringerne ved at leve under et diktatur. Hvordan burde det danske mindretal forholde sig til krav, som knyttede sociale støtteordninger og karrieremæssige fordele til medlemskab i partiinstitutioner? Danskernes forhold til masseforeninger såsom Tysk Arbejdsfront og Hitlerjugend førte til ophidsede diskussioner internt. Mod slutningen af krigen faldt medlemstallet i de danske institutioner til et lavpunkt. Det officielle mindretal var skrumpet ind til sin inderste kerne. Samtidig nærmede det tyske flertalssamfund sig sit totale sammenbrud.

\section{5: En ny begyndelse}

I maj 1945 begyndte et nyt kapitel i den danske befolkningsgruppes historie i Sydslesvig. For en stund virkede det som om dens dage 
som mindretal var ovre. Mange slesvigere havde mistet troen på Tyskland og tilsluttede sig de danske foreninger. I nogle kommuner, deriblandt Flensborg, valgtes danske kommunalbestyrelser.

Denne imponerende ydre styrke rummede imidlertid også strukturelle svagheder. Stort set alle nye medlemmer var opvokset som tyskere; deres omorientering beroede på en viljesakt, som når som helst kunne gøres om igen. For mange indebar en stemme på danske lister ikke nødvendigvis tilslutningen til et dansk mindretal, men udtrykte et ønske om en grænserevision, som man forventede ville give regionen politisk og økonomisk stabilitet. Andre støttede den danske bevægelse for at understrege deres frisiske eller tilmed deres særegne tysk-slesvigske identitet, ofte $i$ afgrænsning til flygtningene fra de prøjsiske østprovinser. ${ }^{7}$ Mindretalspartiet blev belastet af dybe modsætninger mellem en dansk og en slesvigsk-regionalistisk fløj. ${ }^{8}$

$\mathrm{Da}$ det blev åbenlyst, at Sydslesvig ville forblive i Tyskland og flygtningene $\mathrm{i}$ landet, dalede tilslutningen til den danske bevægelse igen. Konsolideringen af den vesttyske økonomi bidrog videre til reintegrationen af midlertidigt fremmedgiorte tysksprogede $i$ flertalssamfundet. Da truslen om grænserevision faldt bort, formindskedes også forsvarsholdningen på tysk side. Derfor lykkedes det mindretallet i 1950'erne at sikre sin retsstilling og sin offentlige forankring.

Mindretallets nøjagtige styrke er vanskelig at slå fast. Efterkrigstidens folketællinger $\mathrm{i}$ Tyskland indeholder ingen information om sprogbrug eller national orientering. Mindretallet selv har heller ikke noget centralt medlemskabsregister. Derfor har forskerne anvendt indirekte kriterier til at bedømme størrelsen af mindretallet. Disse forskellige kriterier udviklede sig imidlertid ikke altid parallelt. Dette vanskeliggjorde præcise styrkeoplysninger og understregede samtidigt det komplekse ved national selvidentifikation i Slesvig.

Aktivt medlemskab af danske foreninger udgør én målestok. Ved siden af de omtrent $\mathbf{1 5 . 0 0 0}$ medlemmer, som Sydslesvigsk Forening havde ved udgangen af det 20 . århundrede, omfattede det danske foreningsliv også cirka 10.000 medlemmer af associerede organisationer. På grund af de mange dobbeltmedlemskaber kan disse to tal imidlertid ikke blot tælles sammen. I tillæg må der ikke ses bort fra, at idrætsforeninger og andre hovedsageligt sociale foreninger også tiltrækker folk, som ikke nødvendigvis opfatter sig som danskere.

En anden målestok er valgresultater. Siden 1948 har det danske 


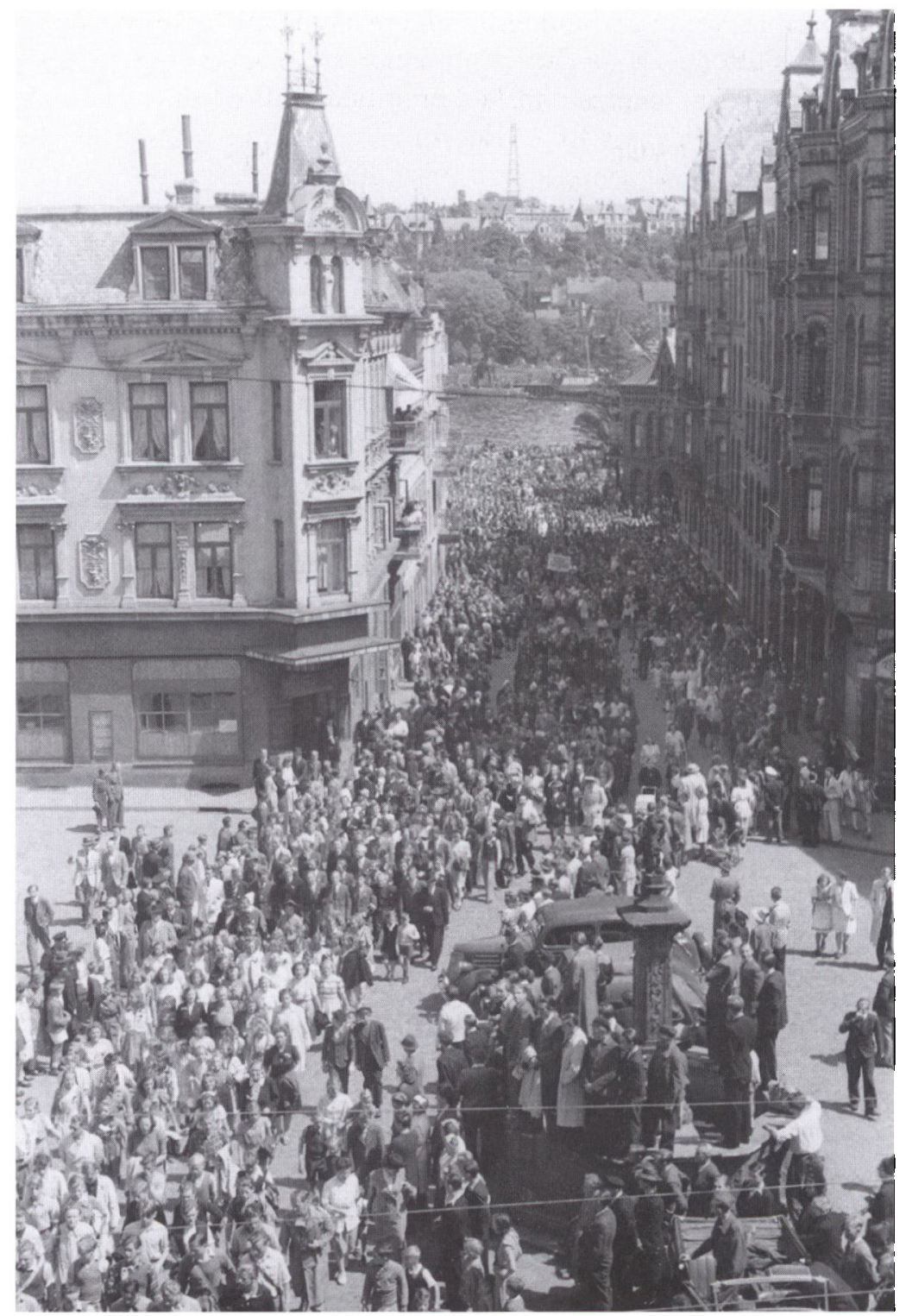

Efter maj 1945 oplevede det danske mindretal i Sydslesvig en eksplosionsagtig medlemsfremgang. I 1933 var der knap 4000 medlemmer af Den slesvigske Forening. I 1948 var medlemstallet knap 75.000. Sydslesvigere, som hidtil havde defineret sig selv som tyskere, bekendte sig nu til danskheden. Situation fra optoget $i$ forbindelse med mindretallets årsmøde i Flensborg i foråret 1946. Foto: Arkivet ved Dansk Centralbibliotek for Sydslesvig. 
mindretal været repræsenteret ved Sydslesvigsk Vælgerforening (SSV). I mellemkrigstiden var mindretallet svagt og opnåede kun mellem 1500 og 7000 stemmer. $^{9}$ Efter Anden Verdenskrig voksede tilslutningen derimod dramatisk. Dette opsving kulminerede ved landdagsvalget i 1947, hvor mindretallet fik 99.500 stemmer. Dette udgjorde omkring en tredjedel af alle stemmer i Sydslesvig, og endda flere af de hjemmehørende. ${ }^{10}$ I 1954 var stemmetallet igen faldet til 42.000, som fortsat svarede til 15 procent i Sydslesvig, men til mindre end 5 procent i den samlede delstat Slesvig-Holsten. Som en del af forsoningsprocessen i grænselandet blev SSV derfor undtaget fra 5\% spærregrænsen i 1955. Partiet har siden hen altid haft mindst én repræsentant i landdagen i Kiel. Mens stemmetallet langsomt faldt til omkring 20.000 i 1970 'erne, voksede det igen i løbet af de efterfølgende årtier. Dette skyldtes ikke mindst tiltagende tilslutning blandt tyske vælgere.

Denne valgtrend bekræfter det særprægede ved mindretalsidentiteten i det dansk-tyske grænseland. En stemme på SSV kan ikke uden videre opfattes som en national stillingtagen. Den store valgsejr i 2000, hvor SSV gik frem fra 38.285 til 60.286 stemmer, beroede nemlig ikke på øget opbakning i Sydslesvig. Faktisk tabte partiet stemmer der. Derimod opnåede SSV omtrent 25.000 stemmer i Holsten, som aldrig havde opvist et genuint dansk element. For at bevare sin beskyttede status som mindretalsparti undlod partiet at opstille kandidater og at drive valgkamp i Holsten. Da en ny valglov alligevel gjorde det muligt at stemme på SSV i hele forbundslandet, benyttede adskillige tyske holstenere sig af denne mulighed.

Derved har det danske mindretal $\mathrm{i}$ de sidste årtier fået stigende opbakning ved valgene, mens dets foreninger har mistet medlemmer. Længe udviklede disse to aspekter sig parallelt. I 1950'erne og 1960'erne lå medlemstallet i SSF tilmed lidt i overkanten af stemmetallet for SSV. Men siden hen skilte de to kurver sig fra hinanden i vælgerforeningens favør. Ved slutningen af det tyvende århundrede havde SSV dobbelt så stor tilslutning som SSF og havde tilmed ekspanderet til Holsten. Flertallet af SSV-vælgerne var ikke længere en del af det organiserede mindretal. 
Tabel 2

Tilslutning til det danske mindretal $i$ udvalgte efterkrigsair

\begin{tabular}{|c|c|c|}
\hline$\AA ̊ \AA r$ & Medlemskab i SSF & Stemmer på mindretalsparti \\
\hline 1947 & 68.317 & 99.500 \\
\hline 1958 & 35.091 & 34.136 \\
\hline 1967 & 25.731 & 23.577 \\
\hline 1979 & 21.425 & 22.291 \\
\hline 1988 & 18.690 & 26.646 \\
\hline 1996 & 16.654 & 38.285 \\
\hline $2000^{11}$ & 15.150 & 60.286 \\
\hline
\end{tabular}

Kilde: Jørgen Kühl, (red.), En europæisk model? (Aabenraa, 2002), 212.

Denne omskiftelighed og flertydighed i mindretalsidentiteten er karakteristisk for Sydslesvig. Men Sydslesvig er ikke det eneste sted i Europa, hvor disse fænomener kan observeres. I flere andre grænseregioner har identitetsdannelsen fulgt et lignende mønster. Nogle af disse bruges til sammenligning her.

\section{Grænsen mellem polsk og tysk}

Langs den tysk-polske sproggrænse fra det sydlige Schlesien til det østlige Masuren eksisterede etniske kontakt- og overgangzoner, som kunne ligge i historisk tyske (Øvre Schlesien) eller polske (Poznańregionen) områder. Etniske forbindelser kunne antage forskellige former. Mange steder boede tyskere og polakker side om side, og familier gik på tværs af de etniske skel. Der fandtes en gradvis tilpasning, hvor isolerede sproggrupper blev assimileret i en større gruppe. Der eksisterede imidlertid også overgangsbefolkninger, som bevarede stærke bånd til begge samfund.

Kasjuberne ved mundingen af floden Wisła/Weichsel er en af de befolkningsgrupper, som blev formet af lang tids samkvem med både polakker og tyskere. De udgør resterne af det tidligere vestslaviske folk pomeranierne, som blev germaniseret efter at deres hertugdømme blev indlemmet i Det tysk-romerske Rige i middelalderen. Under skiftende tysk og polsk overherredømme overtog nogle kasjubere en polsk identitet, andre en tysk, mens andre igen insisterede på at bibeholde en særpræget kasjubisk. Ved begyndelsen af det tyvende århundrede boede der mellem 100.000 og 200.000 kasjubere i distrikter- 
ne omkring havnebyen Danzig/Gdańsk. Deres efterkommere lever der stadig i dag, selvom uddrivelsen af den tyske befolkning i tiden efter Anden Verdenskrig og den efterfølgende polske bosættelse har fremskyndet deres indlemmelse i den polske kultursfære. ${ }^{12}$

Af endnu større interesse for spørgsmålet om omskiftelige identiteter end den kasjubiske er de overgangsidentiteter, som var typiske for det kulturelle landskab i Øvre Schlesien og det sydøstlige hjørne af Østpreussen. I disse områder boede tysk- og polsktalende befolkningsgrupper side om side igennem flere århundreder under et tyskdomineret styre. Mens de to regioner lignede hinanden, så var der også tydelige forskelle. Denne blanding af ligheder og uligheder giver mulighed for at undersøge den relative betydning af individuelle sociale og kulturelle særpræg i dannelsen af national identitet.

Landsbyen Gwozdzice/Gwosdczütz ligger i Opole/Oppeln distriktet i Øvre Schlesien. I Schlesien var den germanske befolkning blevet erstattet af slavere i den tidlige middelalder. I 1100-tallet begyndte tyske kolonister at flytte til regionen. Efter at Schlesien var blevet indlemmet i Det tysk-romerske Rige i begyndelsen af 1300tallet, blev store dele af provinsen tysksproget. Øvre Schlesien, den sydøstlige del af provinsen, forblev dog overvejende polsksproget. Efter Første Verdenskrig tillod de allierede lokalbefolkningen at stemme om deres politiske fremtid. Området blev delt, efter at 707.554 schlesiere havde stemt for Tyskland og 478.820 for Polen. Gwosdczütz forblev tysk indtil 1945, hvor de allierede overdrog næsten hele Schlesien til Polen.

I midten af 1920 'erne erklærede et klart flertal på 71,5 procent af befolkningen i kommunen Rogau/Rogow, hvoraf Gwosdczütz var en del, at deres modersmål var polsk og tysk; 15,66 procent valgte polsk og 12,82 tysk. ${ }^{13}$ En undersøgelse af krigsmindesmærker fra de to verdenskrige i Gwosdczütz viser, at 75 procent af efternavnene er slaviske, hvilket bekræfter det stærke slaviske bidrag til den lokale befolkningsudvikling. Ved folkeafstemningen i 1921 tilkendegav 87,2 procent af befolkningen i Rogau imidlertid deres tyske orientering ved at stemme for en tilslutning til Tyskland. Rogauerne havde hovedsageligt slaviske navne, var tosprogede og definerede sig selv politisk som tyskere. Dette tyder på, at en stor andel af dem, som opfattede sig selv som tyskere, havde stærke slaviske tilknytninger. ${ }^{14}$

Øvre Schlesien påviste, at en betragtelig del af den slavisktalende befolkning i regionen identificerede sig med den tyske politiske sfære, 
Hie Deutschland!

Hie Polen!
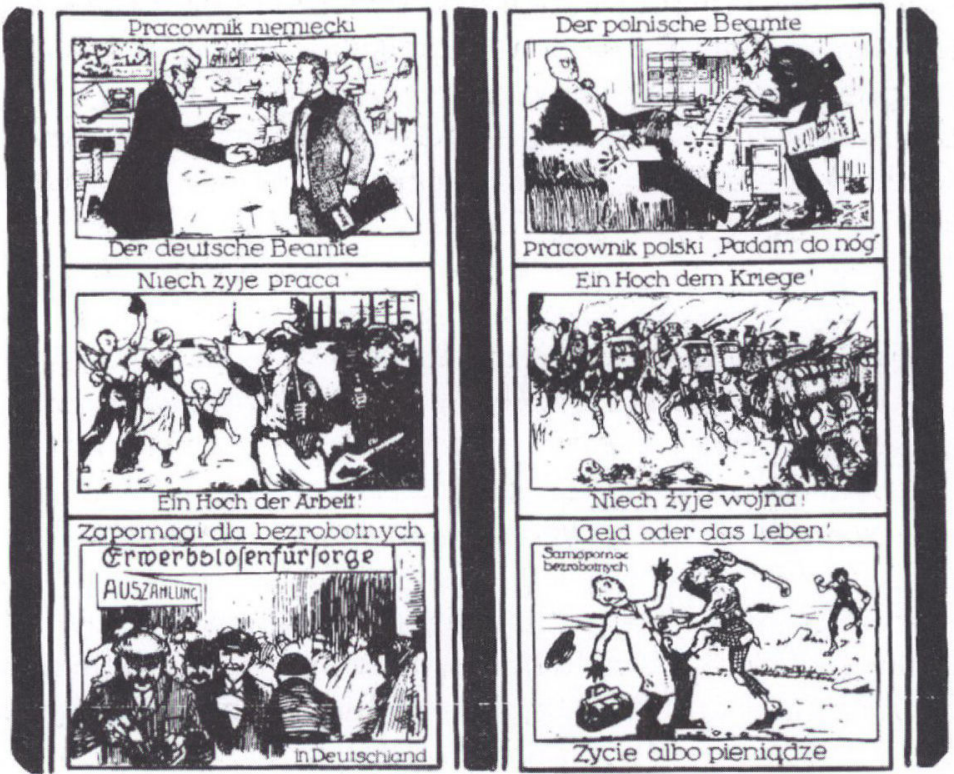

Tu Niemcy!

Tu Polska!

\section{Wiec prawdziwa kartka glosowania jest nastẹpujaca: Also ist für jeden der folgende Stimmzettel der richíge:}

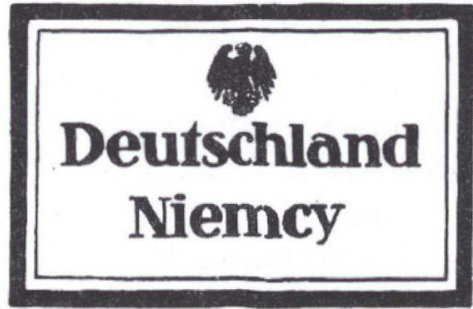

Graphische Kunat-Anstalt ti. a. h. B Breslau 18

Ligesom $i$ Nordslesvig blev der efter Forste Verdenskrig stemt om det nationale tilhorsforhold i Schlesien. Her boede tysk-og polsktalende befolkninger side om side med hinanden. På denne tyske plakat fra afstemningsåret 1921 agiteres der for, at der er store fordele ved at komme til Tyskland: orden $i$ administrationen, arbejde og social sikkerhed. 
men også, at denne identifikation ikke deltes af alle slavisktalende under tysk styre. Selvom Schlesien ikke havde været polsk siden middelalderen, fik den polske bevægelse dog betragtelig styrke. Fyrre procent af alle vælgere i folkeafstemningszonen, og således et flertal af den slavisktalende befolkning, stemte for polsk politisk overherredømme. I Øvre Schlesien var holdningerne delte, og skillelinien gik tværs gennem landsbyer og familier.

I Østpreussen var national identitet mere ensartet, men bestemt ikke mindre interessant $\mathrm{i}$ forskningsøjemed. I starten af 1300 -tallet tillod Den tyske Orden, som regerede over det senere Østpreussen, kolonister fra det polske naboområde Masovien at bosætte sig i den sydøstlige grænseregion. Denne kolonisering tog til i løbet af 1400tallet. De masoviske kolonister smeltede sammen med de lokale tyskere og de indfødte baltiske preussere og blev den dominerende befolkningsgruppe i regionen, som efterfølgende fik navnet Masuren. Masurerne kom til at dele politisk skæbne og luthersk tro med deres tysktalende naboer. De beholdt imidlertid længe deres slaviske sprog. Det var først i løbet af 1800-tallet, at et større antal masurere begyndte at opgive deres gamle dialekt til fordel for tysk.

Selv de masurere, som bibeholdt sproget, var meget svære at nå for den polske nationalbevægelse, som det blev demonstreret af deres konsekvent preussisk-konservative vælgeradfærd. Gennem størstedelen af den wilhelminske tid havde amtet Gumbinnen, som inkluderede det meste af Masuren og Preussisk-Litauen, et af de mest konservative stemmemønstre i Tyskland. I tiden fra 1878 til 1907 fik konservative kandidater regelmæssigt mellem 55 og 80 procent af stemmerne; først i 1912 fik konkurrencen fra de national-liberale skubbet den konservative andel ned under 50 procent. ${ }^{15}$ Polsk-orienterede kandidater overskred kun én eneste gang $10 \%$-grænsen. Dette skete ved valget i 1898, hvor 6000 stemmer gik til et parti med det noget tvetydige navn, Det masuriske Folkeparti. Støtten til dette parti faldt til 4699 stemmer i 1903 og til 1451 i 1907, hvorefter det gik svagt frem til 2698 ud af i alt cirka 70.000 stemmer ved det sidste førkrigsvalg i $1912 .{ }^{16}$

I typisk masuriske valgkredse var resultaterne ofte endnu tydeligere. Med dens $97 \%$ protestantiske og over $55 \%$ slavisktalende befolkning udgjorde valgkredsen Oletzko-Lyck-Johannisburg en af disse udpræget masuriske valgkredse. ${ }^{17}$ Bortset fra 1877 , hvor det gik til en liberal kandidat, gik mandatet i denne valgkreds altid til en konserva- 
tiv, og som regel med et stort flertal. For polske kandidater var det en håbløs valgkreds, som det kan ses af valgresultaterne fra $1903 \mathrm{og}$ 1907.

Tabel 3

Valgresultater for valgkredsen Oletzko-Lyck-Johannisburg i 1903 og 1907

\begin{tabular}{lcc}
\hline Partitilhørsforhold & Andel af stemmer i 1903 & 1907 \\
\hline Konservative & 89 & 94,6 \\
Socialdemokratiske & 6,3 & 2,9 \\
Liberale & 3,9 & 3,8 \\
Polske & 0,7 & 0,2 \\
\hline
\end{tabular}

Kilde: Kaiserliches Statistisches Amt (red.), Statistik der Reichstagswahlen von 1907 (Berlin, 1907), 4f.

Masurerne bibeholdt deres politiske orientering på trods af det tyske nederlag i 1918. I kredsen Sensburg (nu Mraggowo) udgjorde de tysktalende mindre end halvdelen af befolkningen. I folketællingen fra 1900 opgav 20.447 indbyggere i kredsen tysk som deres modersmål, mens 14.704 opgav masurisk, 9784 polsk og 3010 en kombination af tysk og en af de to slaviske valgmuligheder. ${ }^{18} \mathrm{Ud}$ af en befolkning på i alt 48.403 opgav kun 42 procent tysk som deres eneste modersmål. Derfor krævede den polske regering Sensburg og andre masuriske områder indlemmet $\mathrm{i}$ den nye polske stat, da dette spørgsmål blev diskuteret under fredskonferencen ved Versailles. Da de allierede besluttede at løse spørgsmålet gennem en internationalt overvåget folkeafstemning, blev de overraskede af et resultat, hvor kun 25 vælgere i den overvejende polsktalende kreds Sensburg ønskede tilslutning til Polen, mens hele 34.334 foretrak at forblive en del af Tyskland. ${ }^{19}$

Resultaterne fra Sensburg er på linje med det samlede resultat af folkeafstemningen i 1920, hvor 363.209 stemmer faldt til fordel for det tyske Østpreussen og kun 7980 for Polen. Hvis man undersøger tallene nærmere, viser det sig, at de fleste stemmer til fordel for Polen ikke stammede fra Masuren, men fra den katolske region Ermland eller Warmien, hvis sydlige del indeholdt en meget polsk-orienteret befolkningsgruppe. Ud af de næsten 8000 stemmer til fordel for Polen stammede 6002, eller næsten tre fjerdedele, fra afstemningsområdet Warmien, hvor de udgjorde 6,7 procent af det samlede stemmeantal på 89.482. I det protestantiske Masuren udgjorde de 1984 polske stem- 
mer derimod kun 0,7 procent. På trods af deres polske rødder identificerede masurerne sig politisk med Tyskland.

\section{Erfaringerne fra Det habsburgske Monarki}

Konkurrencen mellem den tyske og andre centraleuropæiske nationalbevægelser begrænsede sig ikke til preussiske egne. Habsburgrigets historie har været et klassisk eksempel på national konflikt, og mange fremtræedende teorier om nationalisme og national identitet har taget udgangspunkt $\mathrm{i}$ de habsburgske områder. ${ }^{20}$

Ud over de bøhmiske kronlande, som var præget af langstrakte konflikter mellem tyskere og tjekkere, udviste også alpeprovinserne Steiermark, Kärnten og Kranjsko gnidninger mellem tyskere og slavere. Siden forholdet mellem tyskerne og slovenerne ikke var helt så afgørende for Habsburgrigets fremtid som de tysk-tjekkiske relationer i det velstående og befolkningsrige Bøhmen, har det ikke tiltrukket sig den samme opmærksomhed. ${ }^{21}$ For de involverede befolkningsgrupper var denne konflikt dog ikke mindre vigtig. Samtidig giver den et fascinerende indblik $\mathrm{i}$ den nationale bevidsthedsdannelse blandt kulturelt og politisk ambivalente grænsebefolkninger.

Det kulturelle miljø i sydøstalperne var karakteriseret ved en gradvis homogeniseringsproces. I det overvejende tysktalende Steiermark faldt andelen af slovensktalende fra 32,74 procent i 1880 til 29,38 procent i 1910. Tendensen var endnu tydeligere i naboprovinsen Kärnten, hvor deres andel faldt fra 29,72 til 21,24 procent. I modsætning hertil steg antallet af slovensktalende fra 93,67 til 94,36 i Krajnsko, med en tilsvarende nedgang blandt de tysktalende fra 6,15 til 5,36 procent. Nedgangen var endnu tydeligere $i$ hovedstaden Ljubljana, hvor den tyske andel faldt fra omkring 23 procent i 1880 til mindre end 15 procent i $1910 .^{22}$

Ud over denne overordnede tendens var der lokale modsætninger, som understregede nationalfølelsens potentielle omskiftelighed i grænseregioner. Det der gør denne omskiftelighed særlig interessant, er måden den kom til udtryk på i målinger. De østrigske folketællinger i den sene Habsburgperiode spurgte ikke til kulturel eller national identitet, men til Umgangssprache, som kan oversættes med hverdagssprog. Selvom dette spørgsmål på overfladen var rettet mod objektive kriterier, så fik det hurtigt politiske overtoner, og aktivister på alle sider forsøgte at vende en sprogtælling til en national afstemning. 
Konsekvenserne af denne politisering kan ses $\mathrm{i}$ resultaterne fra de steieriske folketællinger fra slutningen af Habsburgmonarkiet.

Det senere Steiermark har en lang historie for tysk-slavisk sameksistens. De alpeslavere, som flyttede til området efter romernes tilbagetog, var kommet under bayersk overherredømme i den tidlige middelalder og blev integreret $i$ det frankiske og efterfølgende tysk-romerske rige. De østrigske Babenberg-hertuger og deres habsburgske efterfølgere bandt regionen stadig tættere til den østrigske sfære. I folketællingen fra 1880 opgav 794.841 steiere deres talesprog som tysk, mens 388.419 opgav slovensk. Det gjorde provinsen to tredjedele tysk- og en tredjedel slovensksproget. På lokalt plan var befolkningsgrupperne dog ofte skarpt adskilte. De nordlige områder var næsten udelukkende tysktalende, mens de sydlige var overvejende slovensktalende.

Mange byer i det sydlige Steiermark havde imidlertid tyske flertal, og mange af regionens etniske modsætninger opstod i områder, hvor en tysksproget by var omgivet af et slovensktalende opland. De demografiske forhold i det sydlige Steiermark medførte en vis foranderlighed i nationalitetskonflikten, hvilket udgør dens mest iøjnefaldende aspekt. Sprogstatistikkerne fra den lille by Šoštanj/Schönstein viser denne omskiftelighed særligt tydeligt. I Habsburgrigets sidste fire folketællinger fordelte den lokale andel af tysk- og slovensktalende sig på følgende måde:

Tabel 4

Hverdagssprog $i$ Šoštanj/Schönstein 1880-1910

\begin{tabular}{lrcc}
\hline & I alt & tysk & slovensk \\
\hline 1880 & 734 & 118 & 615 \\
1890 & 835 & 410 & 421 \\
1900 & 1096 & 179 & 908 \\
1910 & 1257 & 874 & 368 \\
\hline
\end{tabular}

Selv hvis man tager den betydelige tilflytning, som kommer til udtryk i de voksende befolkningstal, med i overvejelserne, viser tallene en påfaldende omskiftelighed. Beboerne i Šoštanj/Schönstein anså tydeligvis spørgsmålet om deres hverdagssprog som værende rettet mod deres nationale identifikation, da deres daglige sprogbrug næppe kan have skiftet så meget som tallene antyder. De havde tilstrækkelige 
kundskaber inden for de to sprog til at kunne betragte dem begge som potentielle hovedsprog. Folketællingen blev dermed en politisk erklæring. Mange indbyggere følte sig desuden tæt nok på begge nationale samfund til at skifte imellem dem. På et tidspunkt med konflikter mellem tyskere og slovenere i Østrigs alpeprovinser kunne indbyggerne i Šoštanj/Schönstein til tider findes på tyskernes side og til tider på slovenernes.

\section{Konklusion}

Den nationale selvopfattelse langs den dansk-tyske grænse udviser mange variationer. Ved siden af en klassisk nationsopfattelse, som beror på en politisering af kulturelle bånd, udformede sig også en udpræget subjektiv forståelse. Et mindretal af slesvigere formede deres selvidentifikation i modsætning til sin sproglige virkelighed og udfyldte derved den franske filosof og forfatter Ernest Renans aforisme om nationen som en daglig folkeafstemning med konkret indhold. For dem var forskellige politiske, økonomiske og intellektuelle tilknytningspunkter vigtigere end deres kommunikationsmiddel.

Disse ulige udtryksformer har eksisteret ved siden af hinanden. Den danske befolkning i 1800-tallets Sønderjylland bestod overvejende af en førnational regionalbefolkning, som gradvist omdannede sin lokale kulturtradition til en moderne masseidentitet. Samtidig omfattede den dog helt fra begyndelsen også tysksprogede, som bevidst valgte den danske side, ikke mindst i Flensborg. Ved Slesvigs deling i 1920 formindskedes sprogets betydning for den danske identitetsdannelse i Tyskland, og efter Anden Verdenskrig blev mindretallet næsten oversvømmet af tysktalende medlemmer. For nogle af disse var der tale om en gennemgribende omorientering. For andre forblev det nærmest en symbolsk akt.

Disse subjektive og fleksible identiteter er ikke begrænset til Slesvig, selvom de er specielt udprægede der. Undersøgelsen af andre centraleuropæiske grænseregioner viser, at kultur ikke alene udgøres af sprog, men også indbefatter et vidt spektrum af skikke, traditioner og holdninger. Sammen med de andre fremhævede eksempler viser Slesvigs historiske udvikling, hvor kompleks national identitet er. Det gamle hertugdømme gik i opløsning, fordi det i nationalstatens tidsalder ikke længere kunne mestre sin sproglig-kulturelle mangfoldighed. Men på begge sider af grænsen holdt sig mindretal, som ikke 
afledte sin nationale selvforståelse fra modersproget. På den måde bidrager den slesvigske erfaring med en vigtig brik til vor forståelse af, hvad national identitet er.

\section{NOTER}

1. Se Hans Schultz Hansen, Danskheden i Sydslesvig 1840-1918 (Flensburg, 1990), 306-309.

2. Se Paul Selk, Die sprachlichen Verhältnisse im deutsch-dänischen Sprachgebiet südlich der Grenze (Hamburg, 1986), $146 f$.

3. For Clausens forestillinger, se H. V. Clausen, Før afgørelsen (København, 1918).

4. En grafisk oversigt over afstemningsresultatet i Sydslesvig findes i Troels Fink, $\mathrm{Da}$ Senderiylland blev delt (Aabenraa, 1979), 3:41.

5. For de danske valgresultater i Mellemslesvig i det tidlige 20. århundrede, se Hans Schultz Hansen, Danskheden i Sydslesvig 1840-1918 som folkelig og national bevægelse (Flensburg, 1990), 300-309.

6. Johan Peter Noacks egen analyse, som er baseret på bevarede medlemsregistre, når frem til lidt afvigende tal. Bortset fra de lavere tal for 1924, genspejler de imidlertid den trend, som er synlig i de samtidige redegerelser. Se Johan Peter Noack, Det danske mindretal i Sydslesvig 1920-1947 (Aabenraa, 1989), 2:304-25.

7. For en grundig undersøgelse af forholdet mellem flygtningene og den danske bevægelse, se Martin Klatt, Flygtningene og Sydslesvigs danske bevagelse 1945-1955 (Flensburg, 2001).

8. For en undersøgelse af den danske valgbevægelse $i$ efterkrigstidens Sydslesvig, se Lars N. Henningsen, Martin Klatt, og Jørgen Kühl, (red.), SSW: Dansksindet politik $i$ Sydslesvig, 1945-1998 (Flensburg, 1998).

9. Franz von Jessen, Haandbog $i$ det slesvigske spørgsmaals historie 19001937 (København, 1938), 3:523. Tallet refererer til stemmer i Sydslesvig.

10. Se Gerhard Isbary, Problemgebiete im Spiegel politischer Wahlen am Beispiel Schleswig (Bad Godesberg, 1960).

11. Resultatet i 2000 inkluderede omtrent 25.000 stemmer i Holsten.

12. For en introduktion til kasjuberne, se Friedrich Lorentz, Adam Fischer og Tadeusz Lehr-Spławiński, The Cassubian Civilization (London, 1935); Brunon Synak, Kaszubska tožsamóść, (Gdańsk, 1998); og Heinz Lingenberg, "Die Kaschuben « Westpreußenjahrbuch 35 (1985): 123-50.

13. I absolutte tal: 167 tysk; 204 polsk; 931 tysk og polsk. I tidligere årtier, havde der været flere polsktalende.

14. Selvom nogle observatører har prøvet at forklare resultaterne med bredere internationale spørgsmål, såsom Polens militære konflikt med Sovjetunionen, så tyder forskellen i resultaterne, som varierede fra 0,3 procent polske stemmer i Leobschütz/Głubczyce til 74 procent i Pless/Pszczyna, og lighederne i stemmemonstre ved parlamentetsvalg ikke på en ekstern forklaring. En god diskussion af disse spørgsmål i Øvre Schlesien findes i T. Hunt Tooley, National Identity and Weimar Germany: Upper Silesia and the Eastern Border, 1918-1922 (Lincoln, Nebr., 1997).

15. For valgresultaterne, se Gerhard A. Ritter, Wahlgeschichtliches Arbeitsbuch: Materialen zur Statistik des Kaiserreiches 1871-1918 (München, 
1980), 67. De national-liberale var ikke mindre tysk-orienterede end de Konservative.

16. Hans-Ulrich Wehler, »Zur neueren Geschichte der Masuren «, Zeitschrift für Ostforschung 11 (1962): 159f. For den polske nationalbevægelses problemer i Masuren, se også Grzegorcz Jasiński, Mazurzy $w$ drugiej potowie XIX wieku (Olsztyn, 1994) og Heinrich Mrowka, „Die Anfänge einer polnischen nationalen Bewegung in Masuren ", in Hans Hecker og Silke Spiller (red.), Deutsche, Slazven und Balten (Lüneburg, 1989), 128-40.

17. Religions- og sprogoplysninger er baseret på folketællingen fra 1900 .

18. Königliches Statistisches Bureau (red.), Preußische Statistik 177, bd. 3 (Berlin, 1902), 177. Adskillelsen af masurisk og polsk hos ikke bare de tyske myndigheder, men også hos mange masurere, bekræfter deres modvilje mod at identificere sig med Polen. Selvom masurisk indeholdt mange tyske ord og ikke havde gennemgået den samme homogeniseringsproces som det polske sprog, så havde det tydeligvis sine rødder $i$ en polsk dialekt, og en del af masurerne anerkendte da også dette sprogfællesskab.

19. Alle tal angående den østpreussi- ske folkeafstemning er hentet fra Sarah Wambaugh, Plebiscites since the World War (Washington, D.C., 1933), 1:134.

20. Kendte eksempler er Otto Bauers Die Nationalitätenfrage und die Sozialdemokratie (Wien, 1907) og Karl Renners Das Selbstbestimmungsrecht der Nationen (Wien, 1918).

21. Det samlede antal slovensktalende i den østrigske halvdel af riget var ved folketællingen i 1880 omkring 1,1 million, mens der var 5,1 million tjekkisk- og slovakisktalende (slovakisk blev ikke talt separat, men var uden storre betydning). For alle tal fra folketællingen i dette afsnit, se Österreichische Statistik for årene 1882, 1892, $1902 \operatorname{og} 1912$, udgivet af Statistische Zentralkommission $\mathrm{i}$ Wien, og oversigterne $\mathrm{i}$ Emil Brix, Die Umgangssprachen in Altösterreich zwischen Agitation und Assimilation (Wien, 1982), 436-89, Gerhard Werner, Sprache und Volkstum in der Untersteiermark (Stuttgart, 1935), 204f., og Richard Pfaundler, "Die nationalen Verhältnisse in Steiermark am Ausgange des 19. Jahrhunderts«, Statistische Monatschrift 9 (1906): 401-30.

22. Emil Brix, Die Ungangssprachen in Altösterreich zwischen Agitation und Assimilation (Wien, 1982), 181. 